\title{
The Negligence of decoding the Implicatural Insinuations led to a Drastic End: A Case Study of Iago's Monologues in Othello
}

\author{
Sikander Ali ${ }^{\text {** }}$ \\ ${ }^{\text {a }}$ Assistant Professor, Department of English Language \& Literature, The University of Lahore
}

\begin{abstract}
Additional conveyed meaning can be harmful in the certain contexts which may lead the listener to a drastic conclusion. This dictum is quite applicable to the villainous character Iago in Shakespeare's play 'Othello'. Iago is master enough to deal with this implicatural insinuations -additional conveyed meaning indirectly - which desolate the life of at least five characters of the play including the life of his own wife as well. This research deals with the analysis of the certain monologues of Iago to check if there is any flouting of the maxim of quality. Iago is the main villain of the play who wanted to avenge by double knavery. He is the vicious character who flouts the maxim of quality for his certain motives. Grice (1975) is of the opinion that communicational contribution of the participants should be true. This research is descriptive in nature. Qualitative method has been used, by the analysis of a published document i.e. 'Othello' written by Shakespeare. After analyzing the data the result shows that whenever Iago deals with others he flouts the maxim of quality by using implicatural insinuations but he observes it when he is alone.
\end{abstract}

Keywords: Flouting; Implicatural; Maxims; Monologues; Quality.

\section{Introduction}

It is generally assumed that speakers and listeners, involved in conversation, cooperate with each other, and if there is no cooperation that will lead to the non-observance of the Grecian Maxims which ultimately creates Implicature. It is an additional conveyed meaning which is directly link with non-observance of Grecian Maxims, especially the quality maxim - to make communicational contribution that is true (Thomas, 1995). When the play starts two characters - Iago and Roderigo - are in discussion. Both of the characters are talking about the General Othello. Iago is a lower ranked solider who hates the general because he is not promoted. When he is inquired by Roderigo, either he hates the moor or not? Iago says:

\section{"Despise me, if I do not. Three great ones of the city, in personal suit to make me his lieutenant".}

He also mentions that he is capable enough to be promoted as three high ranked officials desires that he should be promoted, because he thinks himself capable for promotion. He is of the opinion that this is part of service, the servants are not promoted by age and service but by the preferences, liking or disliking of the high authorities.

IAGO: Preferment goes by letter and affection, And not by old gradation, where each second Stood heir to the first

Whereas another lower ranked soldier Cassio was promoted. Due to the seed of jealousy which he implanted in himself, started hating both the moor and newly promoted officer. In the consequence Iago started planning to avenge Othello either by hook or crook. That is why; we can see, in most of his dialogues he uses off record -

\footnotetext{
* Corresponding author

Email address: sikandar.ali@ell.uol.edu.pk (Sikander Ali)

DOI: https://doi.org/10.31559/baes2019.3.2.2

Received Date: 23/12/2019

Accepted Date: 22/12/2019
} 
indirect conversation while talking to others to manipulate his vicious plans (Searle, 1975). Iago is a symbol of extreme destructiveness. He wanted to get his place by double knavery. As he said, 'how, how? Let me see'. There are other dimensions, in his monologues, which can be explored i.e. the role of inferences, presupposition and entailment as well. But it would be difficult to manage to all these aspects of Othello in this attempt. Having these considerations in mind, this research deals only analysis of the monologues of Iago with reference of Gricean maxim of quality to explore the hidden motives of Iago. There is no doubt that linguistics and literature are interlinked domains. This research deals with the unification of these two areas i.e. deals with Othello a famous play ever written by Shakespeare and its relation with pragmatic analysis of different situations. This research may be beneficial to both of the literature and linguistics students to improve their vision in this entirely new perspective. Along its new dimension may be explored, because this research deals with the few aspects of pragmatics as well as few fragments of the play Othello.

The focus of this research is only one type of Implicature that is 'conversational implicature' to see how much and why additional conveyed meaning given by lago to achieve his goal.

\section{Literature Review}

Othello is one of the tragic plays ever written by William Shakespeare. In this play a character named Othello; a highly well-regarded general is in the service of Venice. Iago is Othello's ambitious friend (so-called). To achieve his ultimate goal, Iago has to pretend himself the well-wisher of Othello. There is another character named Michael Cassio promoted by Othello which made Iago deadly jealous of this act. Delusions of infidelity affect all of the characters (Todd, \& Dewhurst, 1955). Here starts a rivalry between the hero and the villain of the play but the surprising fact the hero was unaware of this enmity. The plot moves forward when the tragic characters Othello and Desdemona elope, where Iago threw his net to catch fly. Ultimately being poisoned by Iago, the seed of jealousy started growing in Othello.

"The other man in each case is a potential threat to the sexual security and social status of the hero, a threat that is made more real by his being endowed with virtues well known to the hero's wife" (Cohen,1985).

He plans to kill Desdemona but suggested by Iago to asphyxiate her. So the plot reaches at its climax when returns to the citadelin order to kill his guiltless wife. Even supplications of Desdemona couldn't conciliate his wrath. Eventually when the story was exposed to him, the arrow had been slipped from the command (Adamson, 1980). Ultimately when Othello came in his consciousness he wounded Iago, and then killed himself.

As mentioned earlier, this research deals with the pragmatic analysis of the monologues of Iago. Pragmatics is the study of second meaning, not the meaning given by text but by the speaker. It is the study of contextual meaning, when, where and under what circumstances. The term 'Implicature' deals with additional conveyed meaning by referring to what is suggested in an utterance, either expressed or not by the utterance. There are certain types of implicature,

\subsection{Conversational Implicature}

In order to convey an additional meaning, the speaker consciously flouts the maxim/s. For example, a response given by a speaker to a question, "Would you like to go for hunting with us?" with the following utterance:

Well, I have paper tomorrow.

If there was observance of the maxim, the reply would be, simply 'no'. But in spite of the flouting of the maxim of quantity which leads to the flouting of the manner maxim as well, the utterance has an additional conveyed meaning.

Sometimes when the speaker wants to observe the both of the contrary maxims that leads to flouting of any one of the maxims. For example, in a response to a reply, "where is Ali"? the respondent was told the following utterance:

He may be in his room or in the ground.

This is quite interesting; the flouting of one maxim invokes the flouting of the other maxim. For instance, flouting of quantity may invoke the flouting of quality as well rather. In this case, both of the maxims - Quantity and Quality - are in divergence. Here the speaker does not want to be vague as he does not like to give wrong information by giving an exact reply in spite of his indecision (Simon, 1996).

In another case the speaker raises a maxim as a basis for understanding the statement. In the following exchange:

\section{If you please tell me where is the petrol pump?} There is a petrol pump around the street.

Here we see the reply given by the second speaker raises the maxim of relevance which results in the implicature of "the petrol pump is open and one can perhaps get petrol" 


\subsection{Scalar Implicature}

This Implicature deals with certain scales e.g. few, all, some, nothing, entire, etc. For instance,

This signifies that "I did not eat the entire apple."

\section{I ate some of the apple.}

\subsection{Conventional Implicature}

This maxim is not dependent on the cooperative principles or its maxims. A speech always takes its straight implicature.

Adnan is poor but happy.

This signifies that both happiness and poverty are in contrast but still Adnan is happy. Here the word 'but' creates the sense of contrast.

\section{Research methodology}

Qualitative method has been used, by the analysis of a published document i.e. 'Othello' written by Shakespeare. For the analysis purpose the researcher has evaluated the certain extracts of Othello considering in the focus the relevant examples of additional conveyed meaning to see the hidden motives. Few extracts from the monologues of Iago of the play 'Othello' have been taken and investigated through content analysis. According to Holsti, (1969) content analysis is best method for the social sciences and humanities. The analysis of the text of the paper is based on Pragmatics, and more specifically, on the different unspoken devices that help construct conversation, such as implicature.

For the elaboration of the paper different approaches on the implicature have been followed: the principle of Grice (1975) and Bach Kent (1994).

\section{Data Analysis}

The very first line of the play by Iago 'my noble lord' to Othello was said consciously to implant the seed of uncertainty in Othello's mind. This additional conveyed meaning, irrelevant in that context, was given consciously to achieve his vicious goal. The data provided by Iago is not enough to get the communicative intention or the implication of the utterance, when he is in conversation with his general Othello e.g.

IAGO: My noble lord-[94]

There is the use of 'off record' utterance as this utterance is not directly addressed to Othello. In conversation each participant should contribute appropriately. In the following infinitesimal line one can see Iago is less informative than the requisite quantity.

IAGO: Indeed! [101]

We see the information provided by Iago is insufficient, as communicative contribution should be in certain prescribed limit according to the context (Grice, 1975). Whereas in the following quoted line,

IAGO: Think, my lord! [106]

After putting Othello in trouble, Iago was inquired what he was thinking; the reply was quite ambiguous, 'think, my lord'. The question was asked about Desdemona (Othello's wife), either she is honest with Othello or not, what he thinks? But the reply was quite troubling for Othello. In the following dialogue once again there is implicature used by him. And the following example is quite relevant in this context.

IAGO: Good name in man and woman, dear my lord,

Is the immediate jewel of their souls [156]

When Iago says the most precious thing in one's life is the reputation of man and women, actually he wants to refer something to Othello. He is, by using off record utterance, conveying that the name of Othello is at stake, which Othello is unable to infer. His illocutionary act is not decoded by Othello. This complete dialogue shows indirectness used by Iago. He is giving an example of money as in the quoted example "who steals the money steals nothing but who steals reputation he steals everything". This use of additional conveyed meaning via indirectness and off record conversation shows the cunningness of the villain of the play. This is very clearly in this following dialogue of Iago, as once again he wants to inculcate jealousy in the mind of Othello by giving additional meaning which is not required at all.

IAGO: Poor and content is rich and rich enough, But riches fineless is as poor as winter [173]

He is not using truth even if it is truth it is used with bad intention and in wrong context. Further there is no relevance here what he is talking about but he is uttering this for his some specific purposes, to avenge from Othello, which is avenging not revenging according to him. Further, he says 'Oh God, please defend his tribe from jealousy'. There wasn't any need of this example which Iago quoted just to perplex Othello that his name is at stake and at the same time he should not be jealous, though that word 'Jealousy' was out of the context.

IAGO: Good heaven, the souls of all my tribe defend From jealousy! [175] 
Here in the first monologue of lago one can easily find out that how much direct he is in his monologues. Here he is not using off record conversation rather he is using on record conversation. And further there is no additional conveyed meaning in his monologue here. He is confessing how he befools others for the sake of his purse, amusement and for his revenge.

$1^{\text {st }}$ Monologue

Thus do I ever make my fool my purse: For I mine own gain'd knowledge should profane, [380]

Here quantity, manner and relevance maxims have also been observed by him e.g. he is brief, clear and to the point as well and what he is talking about is relevant as well (Grice, 1975).

\section{$1^{\text {stMonologue }}$}

I hate the Moor [384]

In the above quoted line it can be observed when Iago is talking with himself he is lucid and there is truth in his conversation. Further there is bald/on record conversation used by Iago. If he would be in the presence of Othello he never dare to say so.

\section{$1^{\text {st Monologue }}$}

And it is thought abroad, that 'twixt my sheets

He has done my office: I know not if't be true; [386]

Iage has made up his mind that Othello has illicit relations with Emilia (Iago's wife). Othello has replaced Iago on his bed while having relations with Iago's wife. Here there is the case of presupposition when Iago presupposes that Othello has enjoyed illegitimate relations with this wife. At the same time there is flouting of the quality maxims, because he is not sure about this but still believes in self fabricated assumption. This shows that the whole tragedy is based on the presupposition of Iago. In the following monologue, he is making plan to trap Cassio because, according to him, he can be easily trapped.

\section{$1^{\text {st }}$ Monologue}

Cassio's a proper man: let me see now: To get his place and to follow my will In double knavery--How, how?--Let's see: -- [390]

He is using 'on record' conversation here as one can see there straight forwardness and openness in his monologue, whereas talking to others, especially with Othello, he had never ever been so straightforward. Further, once again, there is clarity in his dialogues. The use of directness with himself and indirectness with others is one of his strategies to actualize his plans.

\section{$1^{\text {st }}$ Monologue}

He hath a person and a smooth dispose To be suspected, framed to make women false. [395]

There is bald/on record conversation given by lago, when he says that Cassio has characteristics through which he can be suspected. Iago knows Othello is of a free natured fellow and can easily be befooled. One can see his directness, in the following monologue.

\section{$4^{\text {th }}$ Monologue}

Two things are to be done: My wife must move for Cassio to her mistress; I'll set her on; [355]

Two things he has planned, his wife (Emilia) will send Cassio to beg Desdemona (Othello's wife) for his reinstatement whereas he will bring Othello there who has already been poisoned by his injected poison. In this monologue we can see how straightforward he is, as it has been discussed earlier whenever he is in conversation with others there is use of implicature/off record conversation but when he is alone there is 'on record' conversation as he tries as simple as he can.

\section{Conclusion}

As discussed earlier additional conveyed meaning can be harmful as it leads the listener to a drastic conclusion. The tragedy of Othello is based on this implicatural insinuations used by lago as how he manipulated the situation by using this technique. This act desolated the life of many of the characters. So, the analysis of this study shows that, whenever Iago is in the company of others he flouts the maxim of quality by using implicature, as mentioned in data analysis each and every time he tells lies to Othello and even all of the other characters even his own wife is not safe from him. And further we see there are specific motives behind this use of implicatural insinuations- he wanted to avenge from Othello and to displace Cassio. So it was obligatory for Iago to use it for specific gains. After analyzing the data the result proves that whenever Iago deals with others he flouts the maxim of quality by using implicatures, but he observes it when he is alone.

\section{Biography:}

Dr. Sikander Ali got his doctorate degree from National University of Modern Languages, Islamabad, Pakistan. His research interest lies in Pragmatics, with a special focus on interface between Linguistics and Literature. 


\section{References:}

[1] Adamson. J., Othello as Tragedy, Some problems of judgment and Feeling, Oxford University Press, (1980).

[2] Cohen. D., Patriarchy and Jealousy in Othello and Winter's Tale, Duke University Press, (1985).

[3] Cole. P., The synchronic and diachronic status of conversational implicature. In Syntax And Semantics, 3 : Speech Acts. New York: Academic Press, (1975), https://doi.org/10.1163/9789004368811_011

[4] Davison. A., Indirect speech acts and what to do with them, (1975).

[5] Green. M. How to get people to do things with words, New York Academic Press, (1975).

[6] Grice, Logic and conversation, ibid. Reprinted in Studies in the Way of Words, pp. 22-40. Cambridge, MA: Harvard University Press, (1989).

[7] Hancher. M., Grice's Implicature and Literary Interpretation: Background and Preface, Twentieth Annual Meeting Midwest Modern Language Association, (1978).

[8] Holsti. O. R., Content analysis for the social sciences and humanities, Reading. MA: Addison-Wesley (content analysis), (1969).

[9] Searle. J., Indirect speech acts. Reprinted in Pragmatics: A Reader, ed. S. Davis, Oxford: Oxford University Press, (1975).

[10] Simon. B., Implicature, The Oxford Dictionary of Philosophy, Oxford, (1996), pp. 188-89.

[11] Thomas. J., Meaning in Interaction, London: Routledge, (1995).

[12] Todd. J., \& Dewhurst. K., The Othello syndrome: a study in the psychopathology of sexual jealousy, The Journal of nervous and mental disease, 122(4)(1955), 367-374, https://doi.org/10.1097/00005053-19551000000008 